\title{
THE POLITICAL CONTEXT OF JUDICIAL REVIEW IN INDONESIA
}

\author{
Fritz Edward Siregar*
}

* SJD candidate, Faculty of Law, University of New South Wales Australia

\section{Article Info}

Received : 2 April 2015 | Received in revised form : 31 August 2015 | Accepted : 31 August 2015

Corresponding author's e-mail : fritzsiregar@live.com

\begin{abstract}
The Constitutional Court of Indonesia plays significant role in securing democracy in Indonesia. In exercising their authorities, including the election result dispute and judicial review, the Court continues to affirm institutional judicial legitimacy and pursue their role to guard 1945 Constitution. The first Chief Justice Jimly Asshiddiqie showed how within five years of the Court's establishment, he could strategically maximize its momentum and build the Court as a respectful institution. The Chief Justice Mahfud M D was then elected to reduce the judicial activism started by Jimly's bench. However, against promises and expectations, Mahfud M D brought the Court to a level far beyond the imagination of the Constitution drafters. Parliament and President tried to limit the Court's authority, not ones, and the Court was able to overcome those constrain. Current various available studies observed only how the Court issued their decisions and solely focus to the impact of the decisions. Scholars slightly ignore other constitutional actors in studying about the Court. In fact, political environment where the Court operated is one of the most important aspects which strengthen the Court's institutional legitimacy. This paper attempts to discover the rise of the Court from political environment view outside the court. Political parties' maturity and political constraint are the key factors that support the development of the Court's institutional power.
\end{abstract}

Keywords: judicial review, political context, judiciary, institutional power, political parties, democracy

\begin{abstract}
Abstrak
Mahkamah Konstitusi Republik Indonesia (Mahkamah) memerankan peran yang signifikan dalam mengawal demokrasi di Indonesia. Dalam menjalankan kewenangannya, termasuk di dalamnya penyelesaian sengketa tentang hasil pemilihan umum dan pengujian undang-undang terhadap Undang-Undang Dasar Negara Republik Indonesia Tahun 1945, Mahkamah terus membangun legitimasi institutisinya dalam menjalankan peran sebagai pengawal Konstitusi 1945. Ketua Mahkamah yang pertama, Jimly Asshiddiqie, menunjukkan bagaimana dalam jangka waktu lima tahun dari pendirian Mahkamah, beliau dapat secara strategis memaksimalkan momentum pendirian ini dan membangun Mahkamah sebagai institusi yang dihormati. Kemudian Mahfud M D dipilih sebagai Ketua Mahkamah, dengan maksud untuk mengurangi kegiatan yudisial yang dimulai oleh Jimly dan jajarannya. Namun demikian, berlawanan dengan janji-janji dan harapan-harapan, Mahfud M D justu membawa Mahkamah ke tingkat yang jauh lebih tinggi dari yang semula dibayangkan oleh para pencetus pendirian Mahkamah. Perwakilan Rakyat dan Presiden kemudian mencoba untuk membatasi kewenangan Mahkamah, namun Mahkamah berhasil mengatasi hambatan-hambatan tersebut. Berbagai studi atas Mahkamah saat ini hanya meneliti bagaimana Mahkamah mengeluarkan putusan-putusan dan hanya berfokus pada dampak putusan-putusan tersebut serta acap kali mengesampingkan aktor-aktor konstitusional lainnya. Faktanya, situasi politik di mana Mahkamah berada saat itu merupakan salah satu hal yang terpenting yang dapat memperkuat legitimasi insitusional Mahkamah. Artikel ini mencoba untuk menemukan kebangkitan Mahkamah dari sudut pandang situasi politik di luar Mahkamah. Kedewasaan partai-partai politik dan kendala politis merupakan kunci yang mendukung perkembangan kewenangan institusional Mahkamah.
\end{abstract}

Kata kunci: pengujian undang-undang, konteks politik, peradilan, kewenangan institusi,, partai politik, demokrasi 


\section{Introduction}

The strength of the court is not only determined by how the court exercises their decisions, but also depends on the political environment in which the court is operated. Since its establishment, The Constitutional Court of Indonesia ("Court") has been able to gather support, became strong institution and earned respected from other constitutional institution. To explain this phenomenon, we need to explain the political context in which the court is operated.

The strength of the Court institutional legitimacy has been challenged by President and People Representative Council ("DPR") on two occasions. In response to judicial activism started by the Court since its establishment in 2003, in 2011, DPR issued Law Number 8 Year 2011 regarding the First Amendment on Constitutional Court Law. This law limits court judicial activism by prohibiting the Court from issuing ultra petita decision and order Parliament members to establish Justice Ethic Council ${ }^{1}$ to supervise Court's decision. Through its decision, the Court declared that those restrictions were unconstitutional. ${ }^{2}$ Upon the arrest of Chief Justice Akil Mochtar in 1 October 2013 who was charged with corruption, President issued Government in Lieu Number 1 Year 2013 regarding Second Amendment to Constitutional Court Law. This Government in Lieu which later transform to become Law Number 4 Year 2013 regulates that the nomination to become Constitutional Justice shall be conducted through special committee with its member nominated by Judicial Commission and establishment of Ethic Council. Again, the Court declared that restriction was unconstitutional and declared the whole Law Number 4 Year 2013 to be unconstitutional. ${ }^{3}$

The examples given above are just two examples of how the Court asserts its institutional legitimacy against restriction or backlash that DPR and President try to impose to the Court. Upon two backlash launched by DPR and President, and in addition, the arrest of Chief Justice Akil Mochtar in 2013, the Court was still able to present itself to public as the institution that could be relied upon. The arrest led the Court to the lowest point of their reputation for a while; however, the Court has been able to regain back its legitimacy. It shows how the Court responds to the policy which tries to limit its power by issuing important and highly political decisions in sensitive case such as parallel election case, presidential election case, and legislative election result dispute. Despite all attempt, the Court has been able to produce decisions which are followed by other institutions such as National Election Commission and candidates for presidential election.

The boldness and assertiveness of the Court in exercising the judicial authority, and ability to garner respect from other constitutional institutional shall be explained not only by what the Court did, but also by political context in which the court operates. In this Chapter, the author will attempt to show that the establishment of The Constitutional Court of Indonesia had four things which are counted as essential conditions in supporting the Court's independence and institutional legitimacy.

First, the decision to establish special court outside of existing Supreme Court and the slow process on institutional reformation at Supreme Court led to the increasing trust towards the Court. The decision for not choosing Supreme Court to exercise

\footnotetext{
${ }^{1}$ Justice Ethic Council, according to Law Number 8 Year 2011, is an ad-hoc body that consists of a representative from Parliament, Government, Judicial Commission, Supreme Court and Constitutional Court to decide ethical misconduct allegation towards a constitutional justice.

${ }^{2}$ Court Decision Number 049/PUU-IX/2011

${ }^{3}$ Court Decision Number 001-002/PUU-XII/2014
} 
judicial authority was influenced by past experience towards Supreme Court in which heavily administrated by the Government. It was also because, at that time, Supreme Court Justice was appointed by the President alone, without any interference or parliament's participation. Public expectation of a clean, fast and reliable judiciary wasn't fulfilled by the Supreme Court as the front line of judiciary which manages district court, appellate court and 9 (nine) special courts. Even though it is not realistic to compare reformation in Supreme Court that manages 5000 judges, 13000 court officers that have been distributed around Indonesia, with one (Constitutional) Court which only has 9 Justice and 250 employees, but the Court is able to portray themselves as a better institution than "the other" court. People see and compare the performance of the Court, even during budgetary discussion in the parliament in which the parliament members seek and demand the Supreme Court leader to perform better and take the example from their peer. Therefore, the Court compared to its 'older brother' the Supreme Court does look better.

Second, as the result of democratization in Indonesia, numerous political parties had been created in a short period. Realizing that there is no permanent coalition in the House of Representative ("DPR"), each Law that has been discussed in the DPR has their own coalition because each political party has its own interest. The disappearance of strong and dominant political parties creates lack of control direction of the parliament. With respect to political party obedience towards the Court, even though each political party has their objection and view towards the performance of the Court, but as institution, each political party needs strong Court to settle dispute between them. As political parties' dispute resolution, DPR needs an independent umpire to settle problem between them. In the absence of other institution, the Court will act and there is no other option for DPR other than to support the Court. The latest development, as the result of legislative election 2014, showed the two dominant powers in DPR create deadlock in parliament and give continues uncertainty in legislative power.

The third is the lack of maturity of political parties in Indonesia. Even though this argument is close to the second argument related to the fragmentation of political parties, but it is needed to be discussed in separate arguments because political maturity talks about how leadership of political parties manage political parties as the representation of value and channel of political rights of the people. The failure to become matures on politic for political activism leads the political parties became unpopular actor in Indonesia. As the result, the Court is able to portray themselves in comparison as better image actor. Other consequences for failing to become mature political party are corruption charges towards political parties' activists which are frequently occurred. The unregulated financing of political parties, created the role of the Chairman of political parties to support political parties financially. Therefore, numbers of political parties' members were brought to corruption court. The DPR which consist of political parties have been seen as a corrupt institution. On the other hand, the Court is able to portray as clean and incorruptible institution, except for the case of Akil Mochtar. Unless the Parliament gets its maturity as modern political parties and gets public support with its decision, Court legitimacy will always have higher and stronger institutional legitimacy compared to the Parliament.

\section{The Court's Initial Mandate}

On 9 November 2001, the People's Consultative Assembly ("MPR") enacted the 
Third Amendment to the 1945 Constitution. The Amendment inserted a new Article 24C into the Constitution providing the jurisdiction and powers of the Constitutional Court. ${ }^{4}$ In particular, subsection (1) of this article provides that

the Constitutional Court of Indonesia possesses the authority to hear matters at the lowest and highest levels and to make final decisions on the review of legislation against the Constitution, the settlement of disputes regarding the authority of state bodies whose authority is given by the Constitution, the dissolution of political parties, and the settlement of disputes concerning the results of general elections.

Article 24C (2) further confers on the Court the authority to:

adjudicate on the opinion of People Representative Council regarding allegations of misconduct by the President and/or the Vice President in accordance with the Constitution.

These five areas of authority were carefully chosen. As noted, the basic judicial review authority was conferred in order to guard against the potential abuse of power by the DPR and the President acting together. This form of abuse of power had occurred for 30 years during the Soeharto era and its possible recurrence haunted the constitutional reformation process. In order to ensure respect for individual rights, it was of the utmost importance that the President and DPR should be policed by a separate institution. As we have seen, the discussions regarding the form of judicial review (whether limited or full) and which institution had the authority to conduct judicial review consumed large part of the constitutional drafting process. In the end it was decided that the Constitutional Court's decisions should be final and binding. ${ }^{5}$ The question of which laws should be susceptible to judicial review by the Constitutional Court was settled during the drafting of the Constitutional Court Law of 2003. As enacted, article 50 of the 2003 Law provides that "[ $t$ ]he laws that may be appealed for review are those which have been enacted after the introduction of the amendments to the 1945 Constitution of Indonesia." This limitation on the Court's power is crucial to the political agreement around the establishment of the Constitutional Court, but has since been overturned. ${ }^{6}$

The second power given to the Court is the power to settle disputes regarding the authority of state institutions established under the amended 1945 Constitution. Prior to the amendment, the MPR was recognized as the 'highest' institution, ${ }^{7}$ with the theoretical power to settle all disputes between all other institutions. In fact, however, the MPR had never exercised this power and Indonesian constitutional law scholars agreed that Indonesia under Presidents Soekarno and Soeharto did not recognize the

${ }^{4}$ See also article 10 of the Constitutional Court Law of 2003.

5 Indonesia (1), Undang-Undang tentang Mahkamah Konstitusi (Law regarding Constitutional Court), UU No. 24 Tahun 2003, LN No. 98 Tahun 2003 (Law Number 24 Year 2003, SG No. 98 Year 2003), art. 47. At the time of writing of this article (16 November 2014), the Court had decided 175 judicial review cases out of a possible 650 cases put to in in relation to 325 laws. 24 decisions were related to the settlement of disputes between state institutions.

6 Jimly Asshiddiqie (1), Menegakkan Tiang Konstitusi: Memoar Lima Tahun Kepemimpinan Prof. Dr. Jimly Asshiddiqie, S.H. di Mahkamah Konstitusi, 2003-2008 (Jakarta: Sekretariat Jenderal dan Kepaniteraan Mahkamah Konstitusi, 2008), p 91. Later, the Court declared this article invalid through Court Decision Number 066/PUU-II/2004.

${ }^{7}$ Prior the amendment of 1945 Constitution, MPR has the right to amend the Constitution, elect President /Vice President, and determine the guideline of the State Policy. 
full separation of powers. ${ }^{8}$ The insertion of a judicial review power to settle disputes between constitutional institutions was intended both to recognize the separation of powers and to provide a dispute resolution mechanism between them.

The third power conferred on the Court is the power to dissolve political parties. Under previous regimes, the dissolution of political parties had been used as a tool to curtail political competition. This phenomenon started when President Soekarno dissolved the Masjumi Party (the largest Islamic party) and PSI (Indonesia Socialist Party) in $1960 .{ }^{9}$ President Soekarno later issued a Presidential Decree Number 128 Year 1961 which recognized only eight political parties. ${ }^{10}$ A further decree (Presidential Decree Number 129 Year 1961) dissolved the remaining political parties operating at this time. ${ }^{11}$ President Soeharto was reluctant to have many political parties and urged the integration of existing political parties to form larger groups. ${ }^{12}$ Upon his election in 1971, President Soeharto took over the idea of simplifying the political party structure into distinct factions: the National faction, the Spiritual faction and the Working faction (Golongan Karya). Later, President Soeharto, in Law Number 3 of 1975 regarding Political Parties and Law Number 4 of 1975 further reduced the number of political parties from ten to three. Learning from this past experiences, the constitutional drafters believed that the dissolution of political parties should be regulated by the Court and ensuring that political parties could not be dissolved without the intervention of a neutral umpire.

The Court's fourth power is to settle disputes concerning the results of general elections. Again, this power was included to support the development of political rights and democracy in Indonesia by ensuring that election result disputes would be settled by an independent institution. Before the enactment of this provision, Indonesia had no experience of election disputes since there were, in effect, no competitive elections. ${ }^{13}$ The new authority empowers the Court to decide election result disputes based on an allegation of a mistaken vote count by the Election Commission. Such election results disputes cover all general elections, including the first and second rounds of legislative and Presidential general elections. ${ }^{14}$

The fifth and final power conferred on the Court is the power to adjudicate accusations of wrongdoing made by the DPR against the President or Vice President as part of the prescribed impeachment procedure. As mentioned earlier, this power

8 Lee Cameron McDonald, Western Political Theory: From Its Origins to the Present (California: Harcourt, Brace \& World, 1968), pp. 377-379.

${ }^{9}$ President Sokearno issued Presidential Decree Number 200 Year 1960 and Presidential Decree Number 201 Year 1960 regarding the dissolution of these parties. Prior to these decrees, President had issued Presidential Regulation Number 13 Year 1960 regarding Acknowledgement, Supervision and Dissolution of Political Parties. See also Muhammad Rusli Karim, Perjalanan Partai Politik di Indonesia: Sebuah Potret Pasang-surut (Jakarta: CV Rajawali, 1983), p 147.

10 The eight political parties are: PNI, NU, PKI, Partai Katolik, Partai Indonesia, Partai Murba, PSII dan IPKI. See Jimly Asshiddiqie (2), Kemerdekaan Berserikat, Pembubaran Partai Politik dan Mahkamah Konstitusi (Jakarta: Konstitusi Press, 2005), p 181. Later, President also issued Presidential Decree Number 440 Year 1961 to acknowledge Partai Kristen Indonesia and Persatuan Tarbiyah Islam (Perti). See Karim, op.cit., p. 149.

11 Those parties were: PSII Abukusno, Partai Rakyat Nasional Bebasa Daeng Lalo dan Partai Rakyat Nasional Djodi Gondokusumo.

12 Asshiddiqie (2), op.cit., p 194.

13 During Soeharto's era, the winner of election was the candidate who had been known before the election has been conducted. Golkar Party won with massive support in all election area.

14 Indonesia (2), Undang-undang Dasar 1945 (1945 Constitution of The Republic of Indonesia), art. 24C (1). See also Indonesia (1), op.cit., art. 74(1). 
was one of the driving forces behind the establishment of the Constitutional Court of Indonesia. To that extent, it accords with Tom Ginsburg's insurance theory of judicial empowerment. ${ }^{15}$ However, as noted earlier, empowering the Court to hear impeachment proceedings was not the sole reason for its establishment. While the impeachment of President Wahid (a.k.a. Gus Dur) in 2001 may have brought forward the decision to establish the Court, it wasn't the real reason why Indonesia adopted judicial review. And, as things have turned out, this power has not as yet been exercised, suggesting that it now plays a relatively minor role in ongoing support for judicial review.

\section{III.Factor 1, Slow Reform of the Supreme Court}

\section{A. The Condition of the Supreme Court}

The establishment of the Court wasn't only to fulfill political parties' intention to avoid any such future proceedings through impeachment process at MPR, but it was also to fulfill the Indonesian judiciary's hope for a judicial review function in the years before two consecutive authoritarians. ${ }^{16}$ Before the creation of the Court, the Supreme Court was in bad condition and there was no significant progress in the Supreme Court's performance. Some observers have ranked Indonesian courts as "the worst in Asia". ${ }^{17}$ During President Soekarno's regime, he abolished the separation of powers, allowing executive to interfere in pending cases and intimidated judges directly. ${ }^{18}$ It worsened in Suharto's era when independent judges were discredited and the courts were placed under the Department of Justice. ${ }^{19}$ Incompetent judges were appointed to the Supreme Court, including the chief justiceship. ${ }^{20}$ Cases in the Supreme Court were subject to illegal levies on litigants. The court and its large court personnel had become a front for the collection of bribes. Court personnel withheld issuance of decisions until they were paid illegal fees and sometimes they orchestrated judgments altogether. ${ }^{21}$ For 40 years, Indonesia government had not lost a case in the Supreme Court. ${ }^{22}$

For decades, the Indonesian judiciary has been widely regarded by Indonesians as one of the most corrupt institutions. Surveys indicate that its reputation, ironically, has been for its propensity to act illegally, rather than its capacity to enforce the law, let alone deliver 'justice'.23 There is popular belief which believes most of Indonesia's

15 Tom Ginsburg, Judicial Review in New Democracies: Constitutional Court in Asian Case (Cambridge: Cambridge University Press, 2003).

${ }^{16}$ Sebastian Pompe, The Indonesian Supreme Court: A Study of Institutional Collapse (New York: Cornell University Press, 2005), p 172. See also Susi Dwi Harijanti and Tim Lindsey, "Indonesia: General Elections Test The Amended Constitution and The New Constitutional Court," International Journal of Constitutional Law (January 2006): 146-147.

17 Asian Human Rights Commission, “The State of Human Rights in Indonesia in 2009," p. 20, quoted in Country Research - Indonesia: A Sugarcoated Human Rights System, (Unpublished paper, University of Hongkong Department of Law, May 2010, p.10.

${ }^{18}$ Pompe, op.cit., pp 52 - 64.

19 Indonesia (3), Undang-Undang tentang Ketentuan-Ketentuan Pokok Kekuasaan Kehakiman (Law regarding the Basic Principles of the Judiciary), UU No. 14 Tahun 1970, LN No. 74 Tahun 1970 (Law Number 14 Year 1970, SG No. 14 Year 1970), art. 11.

${ }^{20}$ Pompe, op.cit., pp 111-156.

${ }^{21}$ Ibid., p 163.

${ }^{22}$ Ibid., pp 157-172.

${ }^{23}$ Asia Foundation and AC Nielsen, Survey Report on Citizens Perception on the Indonesia Justice Sec- 
judges and court officials are willing to accept bribes from litigants to secure victory in their cases, with the Supreme Court seen as one of the most corrupt courts in the country. Senior Indonesian judges, including retired Supreme Court Chief Justices, have admitted that there is much in these popular perceptions that is accurate. Former Chief Justice Soerjono, for example, estimated that 50 percent of Indonesia's judges were corrupt. ${ }^{24}$

Court has never been at the forefront in Indonesian history. ${ }^{25}$ During Soekarno's and Soeharto's regime, judiciary lost its purpose except to confirm and to legitimate political status quo. For years the Supreme Court administration (personnel, management, finance, and the structure) is under control of Department of Justice, and the court had limited power to review legislation. ${ }^{26}$

\section{B. Reform of the Supreme Court}

The intention to improve judiciary system has been discussed by constitutional drafters in 1999-2002, during the amendment process, but it was slowly affecting real practical development at Supreme Court. In March 1997, the National Planning Ministry with support by World Bank assisted by two prominent law firm the ABNR (Ali Budiardjo, Nugroho Reksodiputro) and MKK (Mochtar, Karuwin and Komar) drafted judiciary reform initiative and produce a report titled "Diagnostic Assessment of Legal Development in Indonesia". The main issue of the report was on how to increase the capacity of judges and judicial institutions, rather than on judicial integrity. ${ }^{27}$ The fall of Soeharto and economic crisis in Indonesia, led to the establishment of the Commercial Court in Indonesia, as part of the requirement to IMF's support to Indonesia. However, for judges who never handled bankruptcy cases before, the development of commercial court also has its own flaw.

In 2001, Prof. Bagir Manan was elected by President Abdurrahman Wahid as Chief Justice of the Supreme Court. ${ }^{28}$ During that time, the selection of Chief Justice of Supreme Court was conducted through the DPR and the nomination was sent to President for final selection. Prof. Muladi and Prof. Bagir Manan were selected by DPR and President chose Prof. Bagir Manan as the Chief Justice of Supreme Court. Bagir Manan consolidated with other Justices who have mutual idea to conduct reform at Supreme Court. Bagir Manan approached Marianan Sutadi Nasution, Paulus Effendi Rotulung and Abdul Rahman Saleh. ${ }^{29}$ This small group of Supreme Court Justices started to conduct and support reformation process in Supreme Court which was a very close organization. However, to support reformation in massive institution like Supreme Court which supported by small number of people, the reformation was not likely to success. Bagir Manan, before his appointment as Chief Justice, was already close with civic society and he started to communicate reformation agenda. In support

tor: Preliminary Findings and Recommendations, (Jakarta: The Asia Foundation, 2001).

${ }^{24}$ Pompe, op.cit., p. 414.

25 Ibid.

26 Transfer of judicial administration has been realized in 31 March 2004 upon enactment of Law Number 4 Year 2004 regarding Judiciary and Law Number 5 Year 2004 regarding Supreme Court through Presidential Decree Number 21 Year 2004.

27 Dian Rosita (Director, Indonesian Institute for Independent Judiciary (LeIP)), interview by author, 2 July 2014.

${ }^{28}$ The momentum to elect non-career judge to become Supreme Court Justice provided a way for Bagir Manan to enter Supreme Court.

${ }^{29}$ Rosita, interview 
with respective individuals ${ }^{30}$ and legal reform civic society, ${ }^{31}$ in 2003, Supreme Court successfully created a Reform Blue Print of Supreme Court of Indonesia. The relation of Supreme Court with civic society provide further understanding to the Supreme Court that they couldn't continue to conduct the reform without assistance from outside the court. After creating the Blue Print, the second step taken by the Supreme Court was creating Judicial Reform Team. ${ }^{32}$ This team was chaired by Chief Justice of Supreme Court and other internal members from Supreme Court, National Planning Ministry, Minister of Justice, Funding Agency, Advocate, Legal Scholar and Civic Society. This Judicial Reform Team was supported by Judicial Reform Team Office that consisted of Senior Civic Society Legal Reform Activist. However, since early of its creation, Judicial Reform Team Office realized that Judicial Reform Team will not be able to concentrate to conduct reformation program. ${ }^{33}$

Lack of political support, both externally and internally, and massive judicial corruption made the reformation at the Supreme Court progressed slowly and had slow impact. To combat "legal mafia", without providing whole institutional reform agenda, President Susilo Bambang Yudhoyono established a Legal Mafia Eradication Taskforce (Satgas Pemberantasan Mafia Hukum) ${ }^{34}$ This Taskforce operated for two years, until 30 December 2011. The main function of the Taskforce was to make 'coordination, evaluation, correction, and monitoring so that the eradication of the judicial mafia, especially within the police force, the prosecutor's office, the courts, and correctional institutions ('law enforcement institutions'), can be done effectively'. However, as the Taskforce itself notes, this was not an easy task because

The practices of the judicial mafia in Indonesia have been going on for a long time and are carried out using many methods of operation that are increasingly sophisticated. ${ }^{35}$

The decision of constitutional drafter in 1999-2002 for not adding judicial review authority to Supreme Court is clearly understood through the transcript of constitutional amendment process. The number of pending cases and also realizing the Supreme Court Justice was part of the government, and government employed in which selected and trained by Minister of Justice, there is no guarantee that they can perform this highly sensitive authority.

As part of civil servant (government), Supreme Court Justice might have no courage to exercise judicial review authority to declare laws unconstitutional because they are part of government. ${ }^{36}$

Supreme Court has difficulties to be transparent with court management system, and even to publish decisions, it takes longer than Constitutional Court does. ${ }^{37}$

\footnotetext{
${ }^{30}$ Mas Achmad Santosa, Rifqi S. Assegaf, Zacky Hussein, Greg Churchil

31 Lembaga Kajian dan Advokasi untuk Independensi Peradilan (LeIP), Pusat Studi Hukum dan Kebijakan Indonesia (PSHK) and Masyarakat Pemantau Peradilan Indonesia (MaPPI).

${ }^{32}$ The team was formed through the issuance of Supreme Court Chief Justice Letter Number: KMA/26/ SK/IV/2004 regarding Formation of Judicial Reform Team. This is the first legal basis for Judicial Reform Team.

${ }^{33}$ Rosita, interviewed by author.

${ }^{34}$ Legal Mafia Eradication Taskforce was established by Presidential Decree No 37 Year 2009.

35 Legal Mafia Eradication Taskforce, Mafia Hukum (Jakata: UNDP and Legal Mafia Eradication Taskforce, 2010).

${ }^{36}$ Benny K. Harman (Parliament Member, Democrat Party), interviewed by author, 18 June 2014.

${ }^{37}$ Upon strong support from the reform team and civic society, Supreme Court started to publish their
} 
In the rise of Constitutional Court, on Friday, 18 November 2005, Corruption Eradication Commission investigator searched Chief Justice Supreme Court Bagir Manan's Office and questioned him regarding Probosutedjo's case. ${ }^{38}$ The compliance of Chief Justice to be questioning by Corruption Eradication Commission summon had be done upon the interference of President SBY in mediating the rejection of Chief of Justice to be questioning by KPK. ${ }^{39}$ The search of KPK's investigator to Chief Justice's Office was a hard slap to Supreme Court. ${ }^{40}$

\section{Why does this Condition Support Constitutional Court?}

The longing for a clean and accessible Court has been the longing and dream of many Indonesians. ${ }^{41}$ Since its establishment, in short period, the Court was able to fulfill public expectation on a clean and modern court and it was able to provide justice to people. The Court was also able to understand the gap and public expectation from a judiciary, ${ }^{42}$ in which Supreme Court was not able to provide.

As the result, public support towards the court is increasing. Even Parliament members during budgetary meeting or various meeting in which Secretary of Supreme Court and Secretary General of Constitutional Court often compare the performance of the Court and asked the Supreme Court to follow achievement or reform that has been conducted at the Court. ${ }^{43}$ However, the comparison between how the Court handle their court management and how the court use their media relation with others is not comparable between those two courts. As the Supreme Court official repeating counter argument, "It is not fair to compare between Supreme Court and Constitutional Court."

By establishing the Court, the government fulfilled public aspiration. The creation of the Court was done at the correct time when people were losing their trust to the judicial system. Therefore, when the Court was established, there was great expectation from public to a new court. ${ }^{44}$ Realizing the condition of Supreme Court, it is easier to establish new institution rather than to develop new confidence and trust towards the Supreme Court. The authority of the Court is hardly to be inserted into Supreme Court because Supreme Court already occupied with its own internal problem. ${ }^{45}$

decision through Chief Justice Decision Letter Number 11/KMA/SK/VIII/2007 on Free Information at the Court (Keterbukaan Informasi di Pengadilan)

${ }^{38}$ Chief Justice Bagir Manan was in the Panel of Probosutdjo's cases who tried to bribe Supreme Court Justice. Even though Corruption Eradication Commission didn't find anything in their seize to Chief Justice Office, but the effect of their action is unbearable. See DetikNews, "Ketua MA Bagir Manan Diperiksa KPK di Kantornya," http://news.detik.com/read/2005/11/18/084611/480766/10/ketua-ma-bagir-manandiperiksa-kpk-di-kantornya?nd771104bcj, accessed 5 May 2005.

${ }^{39}$ Indosiar, "Presiden Bertemu Ketua MA dan Ketua KPK," http://www.indosiar.com/fokus/presidenbertemu-ketua-ma-dan-ketua-kpk_46458.html, accessed 5 May 2015...

${ }^{40}$ Aria Suyudi (Coordinator, Judicial Reform Team Office, Supreme Court of the Republic of Indonesia), interviewed by author, 4 July 2014.

${ }^{41}$ H. A. S. Natabaya (Retired Constitutional Justice), interviewed by author, 10 December 2013.

42 Ibid.

${ }^{43}$ Personal experience in attending hearing between judiciary institutions in the Parliament.

${ }^{44}$ M. Laica Marzuki (Retired Constitutional Justice), interviewed by author, 19 December 2013.; Rosita, interview.

${ }^{45}$ Jacob Tobing (Constitutional Drafter during 1999-2002 Constitutional Amendment), interviewed by author, 18 August 2014. 
The role of the Court and Supreme Court is not comparable, even though Parliament member, during consultation meeting between Court and Supreme Court always asked Supreme Court to increase their speed in conducting reformation in the Supreme Court. The performance of (constitutional) court is not as result of reform, because reform is something to fix that broken. (Constitutional) Court start from the scratch, and it gives freedom for justice and Chief Justice to design institutional and their staff. ${ }^{46}$

\section{Factor 2, Political Fragmentation}

One of the agendas of the reformation upon the fall of Soeharto was to remove the restriction on political parties. During the Soeharto's era (1966-1998), Indonesia only had three political parties, one of which was in control by the President and became dominant political party. Since 1999, the fragmented party system brought forward party coalitions in most regions. ${ }^{47}$ With a high degree of political parties in which the DPR was divided into four or five main political parties, DPR might as well known as "weak government with high degree of internal conflict and immobilize." 48 The configuration of political parties in Indonesia was unstable from 1999 to 2014, and no party was able to dominate all cabinet in the government. Consequently, consensus and coalition among political parties to achieve a decision-was unavoidable.

The increased number of political parties that participated in the general election 1999 to 2014 was due to several reasons. The 1999 general election was the first general election after the fall of Soeharto in 1998 and the first ever free election after 1950. The 1999 election was also the election in which parliament's members involved and drafted the 1945 constitution amendment.

The 2004 election was the election in which the parliament was living with new constitutional amendment, which also meant that the Court had already operated and was fully functional. In 2004 the Court already conducted their first general election result dispute and has settled 247 election result disputes, in which 38 of parliament members became elected because of the Court's decision. In 2009, 62 seats were exchanged and in 2014 , only 11 seats. ${ }^{49}$

In both new and established democracies, there is a need for parties to work effectively to make democracy works. ${ }^{50}$ One of the important institutional conditions for democracy is a well-functioning political party system..$^{51}$ The role of political parties is not only important, but also crucial because they are the "principal mediators between the voters and their interest." ${ }^{52}$ Political parties are usually established as

${ }^{46}$ Suyudi, interviewed by author.

${ }^{47}$ Particularly for Regional and Head of Regional Election in which political parties often to coalition to nominate their candidate.

48 Donald L. Horowitz, Constitutional change and democracy in Indonesia (Cambridge: Cambridge University Press, 2013), p. 56.

49 In 2009, during Mahfud era, $11 \%$ of the cases was granted and in 2014, during Hamdan Zoelva leadership, the Court only decided $1,1 \%$ of the cases and no change seat for DPR. The Court has moved from substantial justice introduce by Mahfud in 2009 and returned to their original authority in deciding dispute about election result dispute. See Perludem, "Potret Pemilu Dalam Sudut Pandang Sengketa," 2014.

${ }^{50}$ Ulla Fionna, The Institutionalisation of Political Parties in Post-Authoritarian Indonesia (Amsterdam: Amsterdam University Press, 2014), p. 18.

${ }^{51}$ Robert Dahl, On Democracy (New Haven and London: Yale University Press, 1998), pp. 37-38.

52 Richard Gunther, José Ramón Montero and Juan Linz, Political Parties: Old Concepts and New Chal- 
means of articulating similar ideas to strengthen position in order to get similar outcome that meet with their aspirations. ${ }^{53}$ The fragmented political parties shall be observed through election that has been conducted since 1999 until 2014.

\section{Elections upon Reform Era}

The only free national election in Indonesia before 1999 was held in 1955, during a period of parliamentary rule. The 1955's election brought fragmented parliament, in which 28 parties won seats. Four parties, however, received among them about three-quarters of total vote and secured 77 percent of the seats, therefore party support was not impossibly fractured.$^{54}$ However, the 1955 Parliament did not last long, and it seems that parliamentary system did not fit with the Indonesian public. ${ }^{5}$

With a new spirit upon the fall of Soeharto, political parties sought to participate in constitutional change in Indonesia. Out of the 49 political parties registered in general election, 21 won one or more seats in 1999, but the top six political parties won 88,5 percent of the vote. ${ }^{56}$ The top four parties (PDI-P, Golkar, PKB, and PPP) won 79 percent of the votes, and the top two (PDI-P with 33,7 percent and Golkar with 22,4 percent) won more than half the vote themselves. ${ }^{57}$ The change of composition in the DPR was different compared to the previous elections during Soeharto era. Only 20 percent of its members had served in the previous period, and only 10 percent of the elected members were from the civil service or armed forces, compared to 37 percent in the Soeharto-Habibie's era. ${ }^{58}$ For the first time after four decades, Indonesia had freely elected parliament members and those elected members played an important part to undertake constitutional reform in 1999-2002.

With the national election of 2004, the new regulation of political parties was put in place with some changes. ${ }^{59}$ The 2004 election was also the election in which upon the accomplishment of the constitutional reforms from 1999 up to 2002. In 2004, 261 political parties have been registered at Minister of Justice and Human Rights, even though only 24 political parties were eligible to participate in the

lenges: Old Concepts and New Challenges (Oxford: Oxford University Press, 2002), p.. 58.

${ }^{53}$ Fionna, op.cit., p. 16.

${ }^{54}$ Herbert Feith (1), The Indonesian Elections of 1955 (New York: Modern Indonesia Project, Southeast Asia Program, Department of Far Eastern Studies, Cornell University, 1957), pp 58-59.

${ }_{55}$ Some scholars attribute the decline of Indonesian democracy in the 1950 s to an undisciplined military, regional rejection against Java, difference of opinions concerning the role of Islam in the state, or the success of the Indonesian Communist Party. See Herbert Feith (2), The Decline of Constitutional Democracy in Indonesia (Sheffield: Equinox Publishing, 2006). See also R. William Liddle (1), "Indonesia's Democratic Past and Future," Comparative Politics Vol. 24 No. 4 (July 1992): 443.

56148 political parties have been established close to 1999 Election, but only 49 political parties were eligible to participate in General Election.

57 Donald E. Weatherbee, "Indonesia: Electoral politics in a newly emerging democracy" in How Asia Votes edited by John Fuh-seng and David Newman, (New York, Chatham House: Seven Bridges Press, 2002), p. 255. See also R. William Liddle (2), "Indonesia in 1999: Democracy Restored," Asian Survey Vol. 40 No. 1 (Jan-Feb 2000): 32.

${ }^{58}$ National Democratic Institute, "The 1999 Presidential Election, MPR General Session and Post-Election Developments in Indonesia," Kompas (1 October 1999): 15.

59 Indonesia (4), Undang-Undang tentang Partai Politik (Law regarding Political Parties), UU No. 31 Tahun 2002, LN No. 138 Tahun 2002 (Law Number 31 Year 2002, SG No. 138 Year 2002). 
election. ${ }^{60}$ The five largest parties of 1999 remained strong in the parliament, even though the composition of seats changed and distributed more equally. Nearly three-quarters of the DPR members elected in 2004 were newcomers ${ }^{61}$ and proreform political leaders and styles of doing political business. ${ }^{62}$ Moreover, the top five parties in 1999 had 86,5 percent of the votes and 90 percent of elected seats, the same five in 2004 had only two thirds of the votes.

According to Horowitz observation, the seat distribution of the 2004 election result shows that the constitutional drafter (1999-2002) was not wrong when they were worried about fragmentation. However, the constitutional drafter may have not been aware of one of its potential sources which directed presidential elections. ${ }^{63}$ The People Consultative Assembly ("MPR") decision to a separate president election with a 50-percent-plus-one threshold had fundamental effects on dividing supports, voter behaviors, external and internal party relations, and presidential power. ${ }^{64}$

Megawati, as the incumbent President, ran against President Susilo Bambang Yudhoyono (SBY) to the second round of president and vice president election. Initially, political parties' coalition that supported SBY won only one-fifth of all legislative seats and votes. ${ }^{65}$ The SBY ticket even managed to secure large faction of votes from supporters of parties committed to other candidate in the first round. ${ }^{66}$ Fully 82 percent of Golkar supporters and 78 percent of PP supported voted for SBY in the second round, even though their party leaders urged them to vote for Megawati. Even one-third of PDI-P supported deserted Megawati for SBY in the second round. ${ }^{67}$

Even with a majority coalition, the DPR did not become a rubber stamp to support President SBY. The president prevailed on some issues, but not on all. ${ }^{68}$ The initiating role of the president in the legislative process was not always well-received, but it began to take hold. It helped to have majority in the DPR, even though the coalition was not uniformly sustained. Multipolar fluidity and cooperation across party lines were enjoyed, as argued by Horowitz, but they also suffered from cabinet instability, especially for a president so dependent on

${ }^{60}$ Kompas Team, Partai-Partai Politik Indonesia: Ideologi dan Program 2004-2009 (Jakarta: PT Kompas Media Nusantara, 2004). Among those 261 political parties, 26 parties didn't past verification which was conducted by Election Commission, 153 parties has been annulled by Minister of Justice and Human Rights, and 58 parties didn't pass requirements that have been set by Political Parties Law.

${ }^{61}$ Donald L. Horowitz, Constitutional change and democracy in Indonesia (Cambridge University Press, 2013)., p 148.

${ }^{62}$ Edward Aspinall, 'Elections and the normalization of politics in Indonesia' (2005) 13(2) South East Asia Research 117., p 136-38.

${ }^{63}$ Horowitz, op.cit., p 280.

64 Ibid., p. 154.

65 This situation is almost similar with 2014 Presidential Election in which Joko Widodo was supported by only two political parties that only have $25 \%$ seat in DPR.

${ }^{66}$ Aris Ananta, Evi Nurvidya Arifin and Leo Suryadinata, Emerging democracy in Indonesia (Singapore: Institute of Southeast Asian Studies, 2005), pp. 21, 79-89.

${ }^{67}$ R. William Liddle and Saiful Mujani, "Leadership, Party and Religion: Explaining Voting Behavior in Indonesia," Comparative Political Studies Vol. 40 No. 7 (July 2007): 832.

${ }^{68}$ For example, a proposed deregulation of some part of the labor market was held up, not by PDI-P alone, but by Golkar legislators as well. See Damien Kingsbury, "Indonesia in 2006: Cautious Reform," Asian Survey Vol. 47 No. 1 (January/February 2007): 156. It also happened when the President intended to take unpopular decisions to reduce fuel subsidies, a decision which cost him looks bad in the public. 
parties other than his own. ${ }^{69}$

Prior to the 2009 national election, debate to reduce party fragmentation had increased. The debate ranged across three sets of requirements: registration of political parties, eligibility of parties to participate in DPR elections and to win seats, and eligibility to nominate presidential and vice presidential candidates. ${ }^{70}$ The 2008 Electoral Law declared that any party that had been qualified for the 2004 election was automatically eligible to contest in 2009, a provision later found to be unconstitutional by the Court. ${ }^{71}$ Political parties law were designed to provide advantage to large parties and difficulties for smaller or newer political parties to participate in 2009 national election.

The most influential in the electoral result, concerned the establishment of a threshold for DPR. The threshold had not been established for 1999 or 2004 . Against the smaller parties protests, the threshold settled at 2,5 percent for $2009 .{ }^{72}$ Another issue involved what is called in electoral studies district magnitude, the number of seats per constituency in a constituency-list system, such as Indonesia's. In general, the more seats exist, the greater the proportionality and the more opportunities for small parties. The third question related to the rules for acquiring seats on remainders. ${ }^{73}$

In the 2009 national election, only nine parties won any seats at all, compared to 17 that sat in the 2004 legislature. Twenty nine parties, all qualified to participate in 2009 election, received altogether more than 18 percent of the vote, but elected no one to the DPR due to the parliamentary threshold. In this election, 70 the percent of DPR members elected in 2009 had not been in the 2004-2009. ${ }^{74}$

The result of the general election in 2014 was not only an indication of the uprising for the people that participate in the election, but it changes configuration political distribution power in Indonesian Parliament with 10 political parties in the DPR. 2014 Legislative Election created new equilibrium in Indonesia National Parliament. The configuration of power has been changed as summarized below.

\footnotetext{
${ }^{69}$ Horowitz, op,cit., p. 153.

${ }^{70}$ Law Number 2 Year 2008 regarding Political Parties, Law Number 10 Year 2008 regarding Elections of Representative to the DPR, DPD, and DPRD and Law Number 42 Year 2008 regarding Presidential Elections.

71 Indonesia (5), Undang-Undang tentang Pemilihan Umum Anggota Dewan Perwakilan Rakyat, Dewan Perwakilan Daerah, dan Dewan Perwakilan Rakyat Daerah (Law regarding Election of Representative to the $D P R, D P D$, and DPRD), UU No. 10 Tahun 2008, LN No. 51 Tahun 2008 (Law Number 10 Year 2008, SG No. 51 Year 2008), art 8(2). See also Constitutional Court of Republic of Indonesia (1), Constitutional Court Decision Number 21/PUU-VI/2008.

72 Indonesia (5), op.cit., art. 202 (1).

${ }^{73}$ Horowitz, op.cit., p 184.

${ }^{74}$ This Constitutional Court Decision Number 22-24/PUU-V/2008 granted "simple majority" rule and declared unconstitutional "party nomination" for one electoral district. As the consequences, candidate that has more votes shall secure the seat even though their names are at the bottom list of parties' nomination. This composition changed the structure and political in grass root to elect new parliament member at any level.
} 
Table 1: Seats Accumulation on 1999 - 2014 Election $^{75}$

\begin{tabular}{lrrrr}
\hline Political Parties & 1999 Election1 $^{76}$ & 2004 Election & 2009 Election & 2014 Election \\
\hline PDI-P & 153 & 109 & 94 & 109 \\
\hline Golkar & 120 & 128 & 106 & 91 \\
\hline PPP & 58 & 58 & 38 & 39 \\
\hline PKB & 51 & 52 & 28 & 47 \\
\hline PAN & 34 & 52 & 46 & 48 \\
\hline PBB $^{77}$ & 13 & -- & -- & -- \\
\hline PK(S) & 78 & 45 & 57 & 40 \\
\hline PD $^{79}$ & -- & 57 & 148 & 61 \\
\hline Gerindra & -- & -- & 26 & 73 \\
\hline Hanura & -- & -- & 17 & 16 \\
\hline National Democrat & -- & -- & -- & 36 \\
\hline
\end{tabular}

PDI-P obtained the highest vote and was able to secure 109 seats in DPR, however it was not able to hold position as Speaker / Chairman of DPR for 2014 - 2019 i due to the enactment of Law Number 17 Year 2014 on MPR, DPR, DPD and DPRD ("UU MD3").

The previous article regulated selection of leadership stated, ${ }^{80}$

(1) House leadership consists of one (1) chairman and four (4) representatives of the leaders of the political parties are based on the order of acquisition of seats in Parliament; (2) Speaker of the House is a member of Parliament who comes from a political party that gained the most seats in the House first;

The enactment of UU MD3, ${ }^{81}$ article 84 stated,

(1) House leadership consists of one (1) chairman and four (4) representatives of the chief elected from and by the members of Parliament. (2) House leaders referred to in paragraph (1) is selected from and by the members of the House of Representatives in a package that is fixed

The Leader of the House / Speaker of the DPR that previously determined by political parties that most gained seat in the Parliament has changed through selection by the members of the House Representatives. As the result, PDI-P couldn't secure its position as the Speaker of the House.

The 2014 Legislative Election that was conducted in 9 April 2014 was highly

${ }^{75}$ Collected from Election Commission website and Kompas Newspaper

${ }^{76}$ Another 14 political parties gained seat in DPR $(1,2,4$ or 5 seat $)$ but didn't meet election threshold for 2004 election.

${ }^{77}$ PBB accumulation votes did not meet parliamentary threshold for 2004, 2009 and 2014 election

${ }^{78}$ The PK, no longer eligible to participate in 2004, re-registered itself as the PKS for that election

${ }^{79}$ The PD, Democrat Party (Partai Demokrat) the party of 2004 presidential candidate Susilo Bambang Yudhoyono, was a new party, organised before the election

${ }^{80}$ Indonesia (6), Undang-Undang tentang Majelis Permusyawaratan, Dewan Perwakilan Rakyat, Dewan Perwakilan Daerah, dan Dewan Perwakilan Rakyat Daereh (Law regarding MPR, DPR and DPRD), UU No. 27 Tahun 2009, LN No. 123 Year 2009 (Law Number 27 Year 2009, SG No. 123 Year 2009), art. 82.

81 Ibid., art. 85. Law regarding MPR, DPR and DPRD (MD3 Law) is a Law on People Consultative Assembly (MPR), People Representative Assembly (DPR), Regional Representative Assembly (DPR) and Regional People's Representative Assemblies (DPRD). This Law not only governs structure organization of those institutions but also provides detail rules, duty and obligation from respective institutions. 
influenced towards 2014 Presidential Election on 9 July 2014. Having served two terms as President, Susilo Bambang Yudhoyono must step down and new candidates to become President shall be nominated. Jokowi Widodo, Governor of Jakarta ran for President of Republic Indonesia against former three star general and also son in law of President Soeharto, Prabowo Subianto. On 14 March 2014, Mr. Widodo was nominated by PDI-P on less than a month before Legislative Election Day. The nomination was proven to be increasing PDI-P electability in Legislative Election.

As required by Law on Presidential election and Constitutional Courtinterpretation, the nomination of the President was conducted by political parties that participate in general election and win at least 20 percent of seat or 25 percent of the popular vote in the legislative election. ${ }^{82}$ Based on the vote accumulation that has been issued by Election Commission on 9 May 2015, political parties gather their coalition and only two Presidential Pair registered at KPU. ${ }^{83}$ Five political parties supported Jokowi Widodo (PDI-P, PKB, Nasdem, Hanura, PPP). The remaining political parties (Gerindra, Golkar, PAN, Demokrat and PKS) supported Prabowo Subianto.

The legislative election quick count method which published at the end of voting day on 9 April has been proven similar to the official result of Election Commission that decided on 9 May 2015. ${ }^{84}$ Strong desire from PDI-P and their supporting political parties to nominate Joko Widodo became President pushed their parliament members to work on their grass root to support the nomination of Joko Widodo. As the result, PDI-P and other parties that supported Joko Widodo lost their attention in guarding the amendment of UU MD3 Law. In the other hand, the majority party that involved in drafting UU MD3 had foreseen that they must secure their domination in DPR and amended UU MD3 is one of their options. On 5 August 2015, when UU MD3 Law entered into force and the coalition has been formed, PDI-P and its supported political parties roared knowing that they will lose any leadership appointment in DPR.

The lack of clear definition in the 1945 Constitution regards determination of elected President in one round presidential election, lead Constitutional Court to redefine constitutionality presidential election in which contested by two candidates only. ${ }^{85}$ Again, similar to the quick count finding, National Election Commission ("KPU") announced Joko Widodo and Mohammad Jusuf Kalla's obtained the majority vote in 2014 Presidential Election. ${ }^{86}$ Subianto challenged the presidential election result to Indonesia Constitutional Court and the Court rejected Subianto's claim. ${ }^{87}$ Jokowi became the $7^{\text {th }}$ President of Indonesia when he took the oath in front of People Consultative Assembly (MPR) on 20 October 2014.

Political parties that supported Prabowo Sugianto for president created the Red and White Coalition (Koalisi Merah Putih, KMP). On the other hand, political parties that supported Joko Widodo created another coalition which is called Great Indonesia

82 Constitutional Court of Republic of Indonesia (2), Constitutional Court Decision Number 1/PUUII/2004.

${ }^{83}$ Komisi Pemilihan Umum (KPU) (1), Decision Number 453/Kpts/KPU/Tahun 2014 tentang Penetapan Pasangan Claon Peserta Pemilu presiden dan Calon Wakil Presiden Tahun 2014, dated 31 May 2014.

${ }^{84}$ Kompas (1), “KPU Tetapkan Hasil Pileg," Kompas (10 Mei 2014).

${ }^{85}$ Constitutional Court of Republic of Indonesia (3), Constitutional Court Decision Number 50/PUUXII/2014.

86 KPU (2), Decision Number 535/Kpts/KPU/TAHUN/2014 tentang Penetapan Rekapitulasi Hasil Penghitungan Perolehan Suara dan Hasil Pemilihan Umum Presiden dan Wakil Presiden Tahun 2014, dated 22 July 2014.

${ }^{87}$ Constitutional Court of Republic of Indonesia (4), Constitutional Court Decision Number 01/PHPU. PRES-XII/2014. 
(Koalisi Indonesia Hebat - KIH). Horowitz claimed that nomination of political parties is needed only during presidential election; however this claim is not correct to the 2014 Legislative Election. With KMP's coalition holds 313 seat over 247 seat of KIH's coalition, KMP coalition was able to secure all leadership position in DPR. Senior Parliament Member from political parties that support Prabowo Subianto, Golkar Party elected became the Chairman of DPR for $2014-2019 .{ }^{88}$ Realizing that all leadership positions in Committees (Badan) in the Parliament need to be taken through voting / majority votes (as the enactment of UU MD3), KMP left nothing to KIH in Parliament leadership. In response, KIH created their shadow leadership. Parliament meeting has been cancelled and re-negotiation is required to establish a quorum meeting. ${ }^{89}$

\section{How did this Political Situation Support Constitutional Court?}

The consequences of proportional representation on one hand, followed by multi-party system on the other hand, not only-created political fragmentation, but also clearly created the consolidation of political parties in DPR which were fragmented from one election to another. As described above, there were no political parties that become dominant political parties in DPR. Constellation of political parties did not change much, even though institutional breakthrough has been conducted through the enactment of electoral threshold at legislative election 2004.

The main driver for political parties to support the independence of the Court is that they have an interest in the Court's role in maintaining a competitive electoral system. ${ }^{90}$ Realizing the role of the Court to protect democracy and provide adequate rule of law in order to maintain free and fair election, political parties will have ultimate focus to their agenda, in which to get more seat in Parliament. ${ }^{91}$ Even a dominant political party, may have an interest in respecting the independence of a constitutional court if the court is seen to perform some function useful to it. ${ }^{92}$

In Horowitz's view, what dominant parties consistency did for the last 13 years is drafting new laws for each election which is far from standard practice in democracies around the world. It did not only create unstable law from one election to another, but also created battle between large and small political parties. ${ }^{93}$ Those configurations created a factional equilibrium in which Constitutional Court had room to operate with independence, declared government policy unconstitutional, and no one considered disobeying Court decision. ${ }^{94}$ It seems likely that this new atmosphere of political competition freed up the space for Court to build their institutional legitimacy.

In election cases the Court acted as a policy maker by its decision, for example, the decision about determination of seat allocation, through which the

\footnotetext{
${ }^{88}$ Anita Joshihara and Haryo Damardono, “Koalisi Merah Putih Kuasai DPR,” Kompas (2 October 2014).

${ }^{89}$ Ikrar Nusa Bhakti, "DPR yang Terbelah,” Kompas (3 November 2014).

${ }_{90}$ Matthew C. Stephenson, “"When the Devil Turns...”: The Political Foundations of Independent Judicial Review," Journal of Legal Studies Vol. 32 (January 2003): 59.

${ }^{91}$ Theunis Roux, The Politics of Principle: The First South African Constitutional Court, 1995-2005 (Cambridge: Cambridge University Press, 2013), p 21.

${ }^{92}$ Ibid., p 23.

${ }_{93}$ Horowitz, op.cit., p 206.

94 Ibid., p 236.
} 
Court suggested the 'correct way' for determining the allocation of seat. It has decided about the "seat allocation according to phase two and third" by providing interpretation what is the meaning of "open proportionality mechanism" as regulated by article 5(1) Law Number 10 Year 2008 on General Election of National Representative. ${ }^{95}$ Though, in its decision, the Court didn't declare Election Commission Regulated Number 15 (2009) on Seat Allocation Mechanism as invalid. ${ }^{96}$ This conditionally constitutional decision about the seat allocation has been implemented through mechanism that the Court decided. ${ }^{97}$ The Court established its own route to the legitimacy of judicial review through their ability to make useful to political decision makers. ${ }^{98}$

For almost 30 years during Soeharto's era, Indonesia only had 3 political parties. After the fall of Soeharto's regime in 1998, Indonesia conducted election in 1999, followed by 48 political parties. Currently, 10 political parties have seats in DPR. Indonesia constitutional court came to the moment where there was no dominant political party. Comparative studies from Asia, Eastern Europe, Latin American and Middle East support the claim that political party competition provided persuasive explanation on judicial autonomy. As consequences, the absence of centralistic political parties which lead to political fragmentation will support the creation of independent court..$^{99}$ Those fragmented political party provide adequate political environment that support the Court in challenging legislative and executive actions, in which strengthen judicial independence. ${ }^{100}$

In new emerging democracy countries, for example Indonesia, which emerge from intense political conflict and in which there are various ethnics and religions constitutional courts were established precisely for the purpose of preventing those conflicts from shredding the society apart. The Constitutional Court mandate is to guard and to make sure of the constitutional commitment to multiparty democracy and to prevent any effort back into authoritarianism regime, particularly to protect the state from attempt of new kind of authoritarianism as cause of legitimating regular election, but where in fact the democratic system is controlled in favor of a dominant political party. ${ }^{101}$

The fragmentation in parliament also brings chaos in drafting legislation in parliament. Even though the 1945 Constitution provided that a law shall be discussed between Parliament and the President / Government, in practice, the Government needs to negotiate each law with each faction in the Parliament. There is no one voice in the Parliament and the Government needs to meet with each faction and try to accommodate interest from each faction in order to pass legislation products. ${ }^{102}$ As this imbalance situation, government always in the

${ }^{95}$ Constitutional Court of Republic of Indonesia (5), Constitutional Court Decision Constitutional Court Decision Number 110-111-112-113/VII/2009.

${ }^{96}$ Ibid., par. [3.37]

97 Ibid.

${ }_{98}$ Martin Shapiro and Alec Stone Sweet, On Law, Politics, and Judicialization (Oxford: Oxford University Press, 2002).

99 Rebeca Bill Chavez, "Rule of Law and Courts in Democratizing Regimes" in The Oxford Handbook of Law and Politics (Oxford: Oxford University Press, 2008), p. 68.

${ }^{100}$ Helmke G, "The Logic of Strategic Defection: Judicial Decision Making in Argentina under Dictatorship and Democracy," American Political Science Review Vol. 96 Issue 2 (June 2002): 291-303.

101 Samuel Issacharoff, "Constitutional Courts and Democratic Hedging," Georgetown Law Journal Vol. 99 (2011): 980-93.

102 Agus Hariadi (Director of Law and Regulation, Ministry of Law and Human Rights), interviewed by 
losing side in drafting legislation products and therefore, the legislation products are potential to become judicial review cases. ${ }^{103}$

The Court acted as an arbitrator with its final and binding decision for political parties and it became the needs of political parties to settle disputes between them. ${ }^{104}$ Upon handling election result, post-election 2004, 2009 and 2014, the political climate is relatively peaceful because the Court takes control as the electoral dispute resolution. In the other hand, the credibility of other institutions (Supreme Court, DPR, and President) has been questioned. ${ }^{105}$

Individual political party activism or parliament member might not like what the Court does, however, if their political party support and follow Court decision, they will follow and obey Court decision. ${ }^{106}$ Political parties need the Court to settle disputes between them internally or to settle matter with other political parties, and Court decision affect how political parties make their own decision. ${ }^{107}$

As testified by political leader Democrat faction and former Head of Commission III who is responsible for Regulation and Judiciary, "In nature, DPR is a wrestling arena or political lobby (political transaction) to obtain the amount of vote or support." 108

In relation to faction role, the interest of political party leader is dominant. If momentary faction interest is dominant, that is the condition in which a faction will harm public interest. ${ }^{109}$ This momentary interest will escalate support or resistance in drafting a law. As the consequences of this stalling, the constitutionality of the law in question is difficult to achieve and subject to be reviewed by the Court.

Strong and legitimate court is a hope for each institution, including political parties. Political parties need to give up some of their authority to the Court. Political parties relation will create conflict particular because they don't trust one and another what the court do, not only to settle their problem, but also to carry on trust that political parties has given to the Court. ${ }^{110}$

\section{VII.Factor 3, Lack of Political Maturity}

The failure of political party to become mature in the organization, by transforming the political party into a modern political party made the political party became the losing part compared to the Court. As the instrument of democracy, political parties failed to reform itself. It does not mean that the political parties entirely failed to reform their institution as modern institution, but comparing to other institutions as the product of reformation upon the amendment of constitution, the political

\footnotetext{
author, 4 July 2014.

103 Ibid

${ }^{104}$ Ramlan Surbakti (Professor in Comparative Politic, University of Airlangga), interviewed by author, 2 July 2014.

105 Ibid.

${ }^{106}$ Philips Vermonte (Head of Departement of Politics and International Relations, Centre for Strategic and International Studies), interviewed by author, 12 December 2013.

107 Ibid.

108 Benny K. Harman, Negeri Mafia Republik Koruptor: Menggugat Peran DPR Reformasi (Kupang: Penerbit Lamalera, 2012), p. 94.

109 Ibid.

${ }^{110}$ Vermonte, interviewed by author.
} 
parties are late to transform themselves. Parliament members were busy to produce other institutions such as constitutional court, corruption eradication commission, or judicial commission, but they failed to reform themselves.

\section{A. Failed to Train Candidates}

Political parties failed to grow and recruit qualified candidates whom they would be able to nominate to become legislator. Political parties are responsible for recruiting, grooming and maintaining qualified person whom they shall nominate as legislator. In fact, what happened was the Political Parties opened registration to new candidates just before the election, and tried to get more popular people to get more vote to the parties even though such people have no political background or qualification.

Failure of leadership can also be seen in the performance of political parties. There has been almost no attempt by the leaders of the people to support them rationally based on the principle of exchange of support (given the people) with public services (given the elite as compensation). On the other hand, the majority party leadership tends to be trapped into oligarchic, therefore commitment to the democratic process often stops at speeches that does not even embodied in the internal life of the party. ${ }^{111}$ Ironically, the party's leadership remained institutionalized oligarchic although at the same time, the elections choice upon post-Suharto era are direct elections. ${ }^{112}$

Party's internal conflict that leads to disbursement / divide of political party confirms the failure of leader to maintain the political party as well to sustain political party. Lack of leadership in managing the party creates internal conflict which leads to dissolution or disbursement of political parties. ${ }^{113}$ In the past, during Soeharto's era, political party's conflict was the result of state interference to elect party leader. However, upon the reformation era, party's internal conflict still existed to happen. PDI-P internal conflict creates the establishment of Partai Nasional Benteng Kemerdekaan (PNBK), Partai Demokrasi Pembaruan (PDP) and Partai Indonesia Tanah Air Kita (PITA). PAN internal conflict creates Partai Matahari Bangsa (PMB). PPP internal conflict creates Partai Bintang Reformasi (PBR). For losing party that unsuccesfully became chairman in Golkar, they left Golkar and creates new political party. Partai Hanura (Wiranto), Partai Gerindra (Prabowo Subianto), and Nasdem (Surya Paloh). Those were high officials at Golkar who were unsuccessfully secured their seat to become Chairman of Party. Political condition upon the reform support their escape from Golkar and created new political parties and able to gain seat in national and regional parliament.

On the other hand, even though Indonesia recognizes multi-party system, relatively, there was no significant ideological difference between political parties

111 Syamsuddin Haris (1), Masalah-Masalah Demokrasi dan Kebangsaan Era Reformasi (Jakarta: Yayayan Pustaka Obor Indonesia, 2014), p 21. PDI-P phenomenon under the leadership of Megawati Soekarnoputeri and the National Awakening Party (PKB) led by Abdurrahman Wahid, who showed almost identical with the party chairman leader, is a concrete example of the institutionalization of leadership oligarchic parties. Democrats also stricken with oligarchic leadership style at the same time under the leadership of President Yudhoyono also lead upper house party.

${ }^{112}$ Syamsuddin Haris (2), Pemilu Langsung di Tengah Oligarki Partai: Proses Nominasi dan Seleksi Calon Legislatif Pemilu 2004 (Jakarta: Gramedia Pustaka Utama, 2005). See also Kompas Team, Partai-Partai Politik Indonesia: Ideologi dan Program 2004-2009 (Jakarta: PT Kompas Media Nusantara, 2004).

${ }^{113}$ Recent conflict leads to dissolution also faced by Golkar and PPP. 
in DPR. Formally, parties claim that they have different ideology between one and another. However, in politic reality (realties politic), that difference is hardly to be recognized during debate that relate to political issues and policy. ${ }^{114}$ All political parties are able to cooperate one and another disregard ideology obstacle. The consequence of this phenomenon is the political developments in the cartel party system, which is characterized, among others, by the tendency of competition, and cooperation between political parties is more focused to gain rent-seeking policies rather than to fight on the basis of a particular ideology to protect the public interest. ${ }^{115}$ Political cartel phenomenon explained reason for political parties to get closed and look forward to be part of government or state and participate in national economic phenomenon. ${ }^{116}$

Political parties failed to provide qualified legislator because grooming (forming of cadres) fell down. Political parties failed to conduct recruitment and cadres in politic and only act as electoral machine. ${ }^{117}$

There is no political development from 2003 - 2013. Political parties did not educate their members, but it did grow strong enough to build coalition to attack the Court in 2011 and 2013. One of the reasons the political parties failed or refused to reform themselves is because if they do, they will not be able to accommodate political interest or to fulfill interest of the political parties' leaders. ${ }^{118}$

\section{B. The Failure to Reform}

The fundamental reason of why political parties' fail is they do not have clear and transparent funding resources, which lead the members who are seated as parliament members or ministers, to use their office to take state's money illegally. As consequence, numerous of political parties members were arrested for corruption charges. Alternatively, political parties will rely to support from dominant individuals that had vast funding resources to run the parties. As consequence, institutionalization of parties has not worked and parties run according to direction of dominant individual that act as central figure of the parties. In other spectrum, except Akil Mochtar's case, the Court is able to project their institution as a clean and a reliable institution. The quality of political parties, including their members of the parliament confronted with the Court institutional legitimacy will create the Court projecting better image than the political parties.

During the constitutional amendment process, political parties successfully created a new constitution for Indonesia. Political parties were also able to produce institutions that functions well to support democracy process in Indonesia which are Corruption Eradication Commission (KPK) and Constitutional Court, and many other bold innovations. However, political parties failed to reform themselves. If there was a reformation, it goes slowly. Political parties have passed their important moment, what it called "punctuated equilibria". ${ }^{119}$ In punctuated equilibria moment, there is

114 Haris (1), op.cit., p 22.

${ }^{115}$ Kuskridho Ambardi, The Making of The Indonesian Multiparty System: A Cartelized Party System and Its Origin (Ohio: The Ohio State University, 2008).

${ }^{116}$ Haris (1), op.cit., p 23.

117 Harun Husein, Pemilu Indonesia : Angka, Analisis dan Studi Banding (Jakarta: Perludem, 2014), p 63.

118 Djayadi Hanan, (Research Director, Saiful Mujani Research and Consulting), interviewed by author, 16 June 2014.

119 Stephen D. Krasner, “Approaches to the State," Comparatice Politics Vol. 16 No. 2 (January 1984): 
great significant period to conduct reformation because time and situation permit the institution to conduct significant reformation. Once punctuate equilibria moment has passed, it is hard to conduct reformation, and this is what happens to political parties in Indonesia.

As a result of the party system which is still feudal and closed, political parties strategic decisions often ignore the aspirations of the cadre. "Party serves only as a means of channeling political objective of the party owner without try to communicate space dialectic with the cadres," said Yunarto. Meanwhile, researchers Formappi, Lucius Karus, said the current political parties take decisions more on the basis of elite interests, and these interests are not always in line with the party's ideology. ${ }^{120}$

Some studies underline that the institutionalization of democracy during the last decade of relatively more promising than, for example, the Philippines and Thailand. ${ }^{121}$ If the concept of institutionalization of the party system is based on the level of "stability of inter-party competition" as proposed by Mainwaring and Torcal, most political parties in Indonesia is more institutionalized than most of the parties in the two countries. ${ }^{122}$ Similar assessment was proposed by Marcus Mietzner who says that the resilience of the parties in Indonesia is relatively longer, not only in comparison with other political parties in the Philippines and Thailand, but also compared to the political party in South Korea. ${ }^{123}$ Studies conducted by Aspinall and Mietzner underline that if the performance of democratic institutions is able to increase qualitatively, Indonesia will have a promising future. ${ }^{124}$ However, the problem is how to enforce the political parties to work maximally for public interest.

Among other institutions as product of reformation, political parties could not reform themselves. ${ }^{125}$ Political parties are managed by undemocratic, oligarchy and very personality. In addition, the institutionalization of democracy value in determining a key decision or in settling a conflict is very low. ${ }^{126}$

The failure to institutionalize institution creates cartelization among political parties. Cartel describes a situation in which each party disregard their ideologies commitment and program in order to maintain its existence as one group. ${ }^{127}$ The competition between political parties is finished once election period has passed and each parties has secured their seats in the parliament. Ambardi view regards political cartel argument is not really new in regards of the quality of political parties in Indonesia.

One of most cited scholar regarding political party system in Indonesia is Dan Slater who identified the development of political cartel in Indonesia. ${ }^{128}$ Slater argued

223-246.

${ }^{120}$ Kompas (2), "Pemecatan Wanda Bentuk Pemasungan," Kompas (17 September 2014).

121 Andreas Ufen, "Political Party and Party System Institutionalization in Southeast Asia: Lessons for Democratic Consolidation in Indonesia, the Philippines and Thailand," Pacific Review Vol. 21 No. 3 (July 2008).

122 Ibid., p 327.

123 Marcus Mietzner, "Indonesians have a love-hate relationship with their political parties," Inside Indonesia Edition 92 (April - July 2008).

124 Edward Aspinall and Marcus Mietzner, Problems of Democratisation in Indonesia: Elections, Institutions and Society (Singapore: Institute of Southeast Asian Studies, 2010).

125 Surbakti, interviewed by author.

126 Ibid.

127 Ambardi, loc.cit.

${ }^{128}$ Dan Slater, "Indonesia's Accountability Trap: Party Cartels and Presidential Power After Democratic Transition," Indonesia Vol. 78 (October 2004): 61. 
that political parties in Indonesia in the condition in what he called as "accountability trap" which is erupted as the failure of political parties to become check and balance for government. Instead, political parties created a cartel to oppose any opposition to the government. As the result, politic is perceive as big coalition in and the absent of opposition. ${ }^{129}$ As a group, political parties will disregard their pro-public program, as their promise in the campaign, and collectively support government's program. ${ }^{130}$ Slater's argument may be correct for President Susilo Bambang Yudhoyono terms (2004-2014); however it needs to be readjusted for recent development in Indonesia. Two "almost" permanent coalitions in Parliament, as discussed previously, will determine the future of President Joko Widodo's in which his supporting parties are minority in the Parliament.

\section{Corruption}

The democratization process that Indonesia has been through clearly showed that there is no guarantee that democracy will support combat against corruption. ${ }^{131}$ Elections, to achieve democracy, may create a backlash against corrupt practices because it may include vote-buying and money politics which lead to decrease the quality of the democracy itself. Nevertheless, this condition may not ever last long and improvement will come slowly. Research shows that political corruption usually increases in the early stage of democratization but is likely to decline later. ${ }^{132}$ More than a decade after democratic transition, Indonesia has achieved some accomplishments including constitution amendment and equipped new institution, yet Indonesia is still considered as a low-quality democracy country. ${ }^{133}$ One of the factors which support those claims is the abundance of corruption epidemic, which is very closely related to how political parties govern and control their political parties funding.

Political parties which have millions of members and are able to run their organizations and have capability to conduct significant programs, failed to conduct proper fund raising. Parties also failed to report their fund resources, financial reports and fund allocation for their fund.

Political Parties Law ${ }^{134}$ regulates that political parties are able to get funds from member fees, legitimate contribution and state support (national and regional fund). ${ }^{135}$ Legitimate contribution according to Political Parties consists of internal parties (without limitation), and third parties contribution. Third parties contribution

129 Djayadi Hanan, Making Presidentialism Work: Legislative and Executive Interaction in Indonesian Democracy (Ohio: The Ohio State University, 2012).

${ }^{130}$ Ambardi, loc.cit.

131 Yan Sun and Michael Johnston, “Does Democracy Check Corruption? Insights From China and India,” Comparative Politics Vol. 42 No. 1 (October 2009): 1.

${ }^{132}$ Samuel P. Huntington, Political Order in Changing Societies (New Haven and London: Yale University Press, 2006), p. 59;.See also Diamond Larry, Developing Democracy: Toward Consolidation (Baltimore: JHU Press, 1999), p. 240 and Etienne B. Yehoue, Ethnic Diversity, Democracy, and Corruption (International Monetary Fund, 2007).

133 Jamie Seth Davidson, From Rebellion to Riots: Collective Violence on Indonesian Borneo (Singapore: NUS Press, 2009), p. 209. See also Larry Diamond, The Spirit of Democracy: The Struggle to Build Free Societies throughout the World (New York: Macmillan, 2008), p. 220 ("a troubled democracy"); Horowitz use the term "incremental". See Donald L Horowitz, Constitutional change and democracy in Indonesia (Cambridge: Cambridge University Press, 2013).

134 Indonesia (4), loc.cit.

135 Ibid., arts. 34A and 35. 
has limitation IDR 1 billion for personal contribution and IDR 7,5 billion for corporate contribution. State support (national and regional state budget) is a contribution fund to each of the parties that secured a seat in national parliament and regional parliament according to number of votes of their vote. According to national budget, each vote shall be compensated in amount of IDR 108, ${ }^{136}$ unfortunately, regional support differs according to each regional state budget. In Sanggata Regency, Kaltimpost reported that Regency compensates IDR 5.500 per vote or 51 times more than national support for each vote. ${ }^{137}$

The problem of membership fees as a source of party funding, for example, is always listed first in the political party law, but the parties do not use this option effectively. Study by Elections and Democracy Association (Perludem) et al. ${ }^{138}$ found that none of the parties utilized membership fees as their funding resource, both for national and regional level. In the past, Justice Welfare Parties (Partai Keadilan Sejahtera) maximized this method, but it did not last long. This study found that party officials view membership fee or member contribution would cost their members which lead to disincentive to the party institutional strengthening effort. Second, to impose this mechanism is technically difficult to implement. Third, the amount is not significant.

This study estimates that, to run day to day political parties organization secretariat, political education and regeneration, public campaign, and travel, each party needs at least IDR 51,2 billion per year. On the other hand, the average reported parties income is IDR 1,2 billion per year. This created a gap in amount IDR 50 billion and no clear explanation political parties' mechanism to close that. ${ }^{139}$ This situation led party to use other mechanisms to support political parties financial such as elected member contribution and unreported funding contribution. Possibly, this may lead to corruption charge that had been imposed to numerous political parties activist.

Blatant corruption scandals such as report on legislators that were willing to accept bribes in exchange for their support for specific legislations, ${ }^{140}$ has been public knowledge. Another example includes reports of parliament members who allegedly received payments to vote favorably on the confirmation of a senior central bank official $^{141}$ in which KPK alleged 26 Parliament Member from Commission XI received traveler cheque or deleted an entire section on tobacco as an addictive substance from newly enacted health law. ${ }^{142}$ Even, central government departments pay for

\footnotetext{
${ }^{136}$ Minister of Home Affairs of Republic of Indonesia, Minister's Decree Number 212 Year 2010 regarding Financial Support towards Political Parties that Secured Seats at DPR.

137 Husein, op.cit., p. 91.

138 Perkumpulan Untuk Pemilu dan Demokrasi (Perludem) et al., Keuangan Partai Politik : Pengaturan dan Praktek, Kemitraan bagi Pembaruan Tata Pemerintahan (2011).

139 Ibid.

140 Greg Barton, "Indonesia's Year of Living Normally" in Southeast Asian Affairs 2008 edited by Daljit Singh and Tin Maung Than, (Singapore: Institute of Southeast Asian Studies, 2009), pp. 135-36. See also Angus McIntyre, The Indonesian Presidency: The Shift from Personal Toward Constitutional Rule (Lanham, MD: Rowman \& Littlefield, 2005), p. 246 and Freedom House, Freedom in the World 2008 (New York: Freedom House, 2009) pp. 326-25 and Patrick Ziegenhain, The Indonesian Parliament and Democratization (Singapore: Institute of Southeast Asian Studies, 2008), pp. 166-167 and Larry Diamond, The Spirit of Democracy (New York: Henry Holt and Company, LLC, 2008), p. 22.

141 Natasha Hamilton-Hart, "Government and private business: Rents, representation and collective action" in Indonesia: Democracy and The Promise of Good Governance edited by Ross H McLeod and Andrew MacIntyre, (Institute of Southeast Asian Studies and the Indonesia Project of the Research School of Pacific and Asian Studies, The Australian National University, 2007), pp. 93, 110-111.

${ }^{142}$ Suara Pembaruan, “Inilah Peta Korupsi Yang Terjadi di DPR RI [Corruption Mapping in Parliament]”,
} 
legislation, and regional governments pay for the release of central government funds. ${ }^{143} \mathrm{KPK}$ also arrested Parliament Member from Commission IV with Province Secretary (Sekretaris Daerah) regards conversion of protected forest in Bintan, Province of Riau. ${ }^{144}$

Presidential election is not easy when President had to satisfy many parties, including satisfying the coalition. Political parties that join for coalition in 2004 and 2009 rushed for ministries, which use the ministries as sources of party revenue and administration. ${ }^{145}$ The important and increasing role of money in presidential campaign, beginning in 2009, will make anti-corruption efforts more difficult, for much of the corruption in Indonesia is not to enhance private welfare but to meet the needs of political parties and candidates. ${ }^{146}$ All parties require payments to survive. ${ }^{147}$ Research shows that 22 of the 70 ministries and government agencies of the Indonesian central government have foundations (Yayasan) or affiliated with them, and at least 46 of them, utilize state assets and those foundations are often not audited by the Government Audit Board (Badan Pemeriksa Keuangan).

Even though Indonesia tried hard to work on it, nevertheless, on Transparency International's Corruption Perception Index 2004 to 2013, Indonesia moved from a score of 2.0 to 3.2, a slight improvement, even though still left it below India, Thailand, and China. ${ }^{148}$ In a 2010 survey, 69.1 percent of responses declared that the level of corruption in Indonesia was high or very high, ${ }^{149}$ and fewer responders believed the struggle against corruption was going well or pretty well than had though so previously (by only 51 percent to 84 percent in mid-2009). As the result, even though most supporters of certain political parties did not believe their parties put the public interest first, in fact, frustration towards political parties was at a very high level. ${ }^{150}$ This condition certainly leads to delegitimized public support towards political parties, in which DPR is their institution that they represent with.

Transparency International found out that political parties and parliament are the most corrupt institution in Indonesia and politician is the most corrupt actor, ${ }^{151}$ followed by Judiciary and Police. Public trust towards political parties is also in the lowest point, compared to public trust towards military, government (central and

http://www.suarapembaruan.com/home/inilah-peta-korupsi-yang-terjadi-di-dpr-ri/42900, accessed 4 August 2014.

143 Harold A. Crouch, Political Reform in Indonesia After Soeharto (Singapore: Institute of Southeast Asian Studies, 2010), pp. 70-73. Government bodies, business firms, and societies have been known to pay DPR commission chairs for the approval of proposed legislation. See also William Case, Executive Accountability in Southeast Asia: The Role of Legislatures in New Democracies and Under Electoral Authoritarianism (Honolulu: East-West Center, 2011), p. 27.

${ }^{144}$ Kompas, "Amin Nasution-Azirwan Tersangka Penyuapan [Amin Nasution-Azirwan Bribery Suspected]", 10 April 2008.

145 Horowitz, op.cit., p. 153.

146 Legislative candidate and Head or Vice Head Regional.

147 Horowitz, op.cit., p. 223.

148 Deborah Hardoon and Finn Heinrich, Global Corruption Barometer 2013 (Transparency International, 2013). The scale ranges from 0 to 10 , from high to low corruption.

${ }^{149}$ Lembaga Survei Indonesia, "Ketidakpercayaan Publik Pada Lembaga Pemberantasan Korupsi [Public Distrust of Bodies Fighting Corruption]” (Report of a survey conducted nationally, 10-22 October 2010), p. 14.

150 Paige Johnson Tan, "Anti Party Reaction in Indonesia: Causes and Implications," Contemporary Southeast Asia Vol. 24 No. 3 (December 2002).

151 Hardoon, Deborah and Finn Heinrich, op.cit., p. 36. 
regional), police and parliament. ${ }^{152} \mathrm{~A}$ similar indication can be found, either from the unfolding of various cases of abuse of budget funds by party politicians in Parliament, as well as the general public perception of the party's performance. ${ }^{153}$

People are questioning the quality of parliament members because of money politic in the election. Massive money politic during general election is something that people could not deny. As consequences, things that Parliament does never get appreciation from public. ${ }^{154}$

The failure to groom and reform its institution also affect the political parties decision to select their candidates to become parliament members. CSIS research showed that $82 \%$ of people have no knowledge about their representatives. ${ }^{155}$ Election system that has been created that doesn't support district mechanism lead less accountability from elected parliament member to their constituent. That is also the result of no relation between constituent and their parliament member. It led also to election 2014, when people were likely to vote for political parties, instead of choosing a person. In 2009 elections, people may vote for their representatives or political parties, and the repeated voting behavior to vote political parties in 2014 elections proved disconnection between candidature and constituent.

The quality of parliament members in 2009 - 2014 was better than previous generation. They had better education background than the previous generation. $70 \%$ of them are new parliament members compared to 2004-2009 and most of them were entrepreneurs or former government officials. ${ }^{156}$ The 2009 Member of Parliament were younger, had better education, but most of parliament members did not have adequate political experience. Statistically, they have no experience in politics. ${ }^{157}$

Majority rule decision increases the change for the parliament member candidate which intends to increase their electability percentage. For parliament members who have money, majority rule mechanism creates opportunity for them to get elected. Compared with proportional rules, political parties have the right to choose their candidates. As the consequences of majority rule, the candidate is not required to be involved in political party machine to win the election, but they can use their own resources. ${ }^{158}$ In this matter, money politic plays as an important part.

Indonesia already decided to choose between district and proportional representation. Method of proportional representation in combined with majority vote rule that has been applied since 2009 Legislative Election created newly type of parliament member. As testified by leader of PDI-P faction,

In order to become parliament member, we have to fight internally with other fellows from same political party. Political recruitment that what we intend, it is not happening. If we have close recruitment system, political party can give punishment to

152 Syamsuddin Haris (3), Praktik Parlementer Demokrasi Presidensial Indonesia (Jakarta: CV. Andi Offset, 2014), p. 174.

153 Pramono Anung Wibowo, Mahalnya Demokrasi, Memudarnya Ideologi: Potret Komunikasi Politik Legislator-Konstituen (Jakarta: Penerbit Buku Kompas, 2013).

154 Harman, interviewed by author.

155 Vermonte, interviewed by author.

${ }^{156}$ Ronald Rofliandi (Researcher and Director, Indonesian Centre for Law and Policies Studies (PSHK)), interviewed by author, 11 December 2013.

${ }^{157}$ Eryanto Nugroho (Researcher and Executie Director, Indonesian Centre for Law and Policies Studies (PSHK)), interviewed by author, 11 December 2013.

${ }^{158}$ Rofliandi, interviewed by author. 
their member who is doing wrong or not performing. It (majority vote rule) changes political structure. No wonder why we have Parliament Member with this quality and make democratization process goes slowly because we cannot choose the smartest people in the political parties. They lost with the people who have money and competence to increase their vote. ${ }^{159}$

Larry Diamond writes that even though political rights and civil liberty in Indonesia increases rapidly significant compared to Thailand and the Philippines, however, good governance, policy and rule of law decreases compared to India and those countries. ${ }^{160}$ Bappenas and UNDP report regards Index Democracy in Indonesia reported that even though index of political rights are relatively high, however index of institution of democracy (election, parliament, political parties and bureaucracy) is low. ${ }^{161}$

It is hard to deny that democratization upon the fall of Soeharto's regime has increased rapidly, for example the amendment of constitution, democratic election and direct election to elect president, vice president and head of regional. However, in the same time, the understanding towards politic, political party, election, democracy and essence of good governance itself has been significantly decreasing for the last decade. As the result, political parties that should be considered as a channel and forum to serve, train and increase political awareness of public, lately has become as forum to get an employment in the real meaning. ${ }^{162}$ Elections in Indonesia tend to be more conducive for free and democratic members of parliament who are likely just ready to "take" rather than leaders who are responsible, and to serve the people.

As argued by Haris, freedom of association which encourages the formation of dozens of political parties post-Soeharto, seemly not changing the character of political parties. Instead, political parties inherited structural failure likewise before the post-Soeharto. ${ }^{163}$ Consequently, there is almost no tradition of rationally organized, democratic, and responsible in the political parties. It is common that decisions and political choices determined by a handful political parties leader or even a party leader. ${ }^{164}$ Ironically, there is no dedicated and serious attempt from political parties to change or reform this situation. Political leaders in fact exploit this situation to maintain their power. ${ }^{165}$

There is no public demand towards political parties to conduct reform within themselves. The current election system lead that there is no need for political parties to become accountable to public. ${ }^{166}$ Election system that created by parliament itself produce a situation in which a political party only need public vote for five yearly term. There is no need for parliament member or political parties to take care their constituent or make them accountable to their constituent. When they need political support from constitution that is where money political will play. ${ }^{167}$

${ }^{159}$ Yasonna Laoly (Parliament Member, Indonesian Democratic Party-Struggle), interviewed by author, 8 December 2013.

160 Larry Diamond, "Indonesia's place in global democracy" in Problems of Democratisation in Indonesia: Elections, Institutions and Society, edited by Edward Aspinall and Marcus Mietzner, (Singapore: ISEAS, 2010), p. 51.

161 Haris (1), loc.cit.

162 Ibid., p. 18.

163 Ibid., p 178.

164 Ibid.

165 Ibid., p 179.

${ }^{166}$ Surbakti, interviewed by author.

167 Ibid. 


\section{Why does this Condition Support Constitutional Court?}

During democratization process in Indonesia, and dealing with political immaturity and weakness of representation or other political institution, it makes the role of constitutional court became critical, because the immaturity of political parties also happens in other society that participate in democratic life. ${ }^{168}$ Marcus Mietzner argued that the failure of political parties to settle their issues makes the Court become political parties' dispute resolution for them. ${ }^{169}$ Individually, political parties member may not like or disagree with Court decision, but institutionally, political parties need to strengthen and respect Court independence because the Court acted as umpire for political parties. ${ }^{170}$

During that time, the Court was able to provide them as a clean and effective Court. The Secretary General of the Court received "disclaimer regards financial report" in which the first time for the judiciary institution to have that rewards from Ministry of Finances. Secretary General of the Court continuously received this award since 2004 up to 2014.

Even though the Court was created through constitution amendment, political parties supported the creation of the Court. However, upon the establishment of the Court, the Court turn their back and start to review what the political parties had produces. The Parliament has no leverage to attack or revise the Court through other mechanisms. It is realized that the Court has public support, which is something that the Parliament does not have. ${ }^{171}$ The only way for the Parliament to remind the Court, is through trying to reduce their authority.

The Court is not entirely clean in this matter. The Court also contributes by deciding the case in majority vote to elect Member of Parliament. ${ }^{172}$ As the consequences, the most popular voted candidates shall seat at the parliament member, and that is usually, the people who have more money and influence. It is not necessary that they are people who have credibility to become parliament members.

As the result of failing to reform themselves, public perception see that political parties have not changed from past regime into present situation, that is always negative. Public views that political parties are collections of people who seek to become in power and they can change their political parties' background as their change their clothes. ${ }^{173}$ Political parties are only tools to achieve power and not used as institution that need to be develop to fulfill public expectation. As the result, legitimacy of political party is very weak.

Because Parliament is the arena for political parties', as the consequences, Parliament legitimacy also goes down as the political party legitimation. It is confirmed with survey from various survey institutions or national newspapers from time to time.

\footnotetext{
168 Issacharoff, op.cit., p. 1003.

169 Aspinall, Edward and Marcus Mietzner, loc.cit.

170 Vermonte, interviewed by author.

171 Hanan, interviewed by author.

172 Constitutional Court of Republic of Indonesia (6), Constitutional Court Decision Constitutional Court Decision Number 22-24/PUU-V/2008.

${ }^{173}$ Hanan, interviewed by author.
} 


\section{Conclusion}

Those three factors support the legitimacy of the Court and provide space in which the Court is able to interfere political sphere in Indonesia politic.

Political fragmentation helped to increase court legitimacy and judicial independence. With its judicial review authority, the Court is able to strike down law that intended to reduce court judicial activism. The coalition is only able to gather their power to produce a law to amend constitutional court law, but was not strong enough to amend the Court through constitutional amendment. There is one thing to attack the court from legislative perspective, and also it is another thing to gather coalition to amend the constitution to reduce court's authority.

The argument stated that corruption is one of the key factors which degrading political parties' legitimacy and is not a newest finding in Indonesia context. However, if this practice continues, public perception will not change towards Parliament in which will make the Court has better position in public image.

The question on until how far the Court will be able to interfere and conduct judicial activism in Indonesia context needs further research. When democracy is already in place, constitutional system is starting to work, and role of the Parliament as representation of people has been strengthened, there should be a limitation of Court's power.

\section{Bibliography}

\section{Legal Documents}

Constitutional Court of Republic of Indonesia. Constitutional Court Decision Number 21/PUU-VI/2008.

Constitutional Court of Republic of Indonesia. Constitutional Court Decision Number 1/PUU-II/2004.

Constitutional Court of Republic of Indonesia. Constitutional Court Decision Number 50/PUU-XII/2014.

Constitutional Court of Republic of Indonesia. Constitutional Court Decision Constitutional Court Decision Number 22-24/PUU-V/2008.

Constitutional Court of Republic of Indonesia. Constitutional Court Decision Number 01/PHPU.PRES-XII/2014.

Constitutional Court of Republic of Indonesia. Constitutional Court Decision Constitutional Court Decision Number 110-111-112-113/VII/2009.

Indonesia. Undang-Undang tentang Mahkamah Konstitusi (Law regarding Constitutional Court). UU No. 24 Tahun 2003, LN No. 98 Tahun 2003 (Law Number 24 Year 2003, SG No. 98 Year 2003).

Indonesia. Undang-undang Dasar 1945 (1945 Constitution of The Republic of Indonesia). Indonesia. Undang-Undang tentang Ketentuan-Ketentuan Pokok Kekuasaan Kehakiman (Law regarding the Basic Principles of the Judiciary). UU No. 14 Tahun 1970, LN No. 74 Tahun 1970 (Law Number 14 Year 1970, SG No. 14 Year 1970).

Indonesia. Undang-Undang tentang Partai Politik (Law regarding Political Parties). UU No. 31 Tahun 2002, LN No. 138 Tahun 2002 (Law Number 31 Year 2002, SG No. 138 Year 2002).

Indonesia. Undang-Undang tentang Pemilihan Umum Anggota Dewan Perwakilan Rakyat, Dewan Perwakilan Daerah, dan Dewan Perwakilan Rakyat Daerah (Law regarding Election of Representative to the DPR, DPD, and DPRD). UU No. 10 
Tahun 2008, LN No. 51 Tahun 2008 (Law Number 10 Year 2008, SG No. 51 Year 2008).

Indonesia. Undang-Undang tentang Majelis Permusyawaratan, Dewan Perwakilan Rakyat, Dewan Perwakilan Daerah, dan Dewan Perwakilan Rakyat Daereh (Law regarding MPR, DPR and DPRD). UU No. 27 Tahun 2009, LN No. 123 Year 2009 (Law Number 27 Year 2009, SG No. 123 Year 2009).

\section{Books}

Aspinall, Edward and Marcus Mietzner. Problems of Democratisation in Indonesia: Elections, Institutions and Society. Singapore: Institute of Southeast Asian Studies, 2010.

Dahl, Robert. On Democracy. New Haven and London: Yale University Press, 1998.

Fionna, Ulla. The Institutionalisation of Political Parties in Post-Authoritarian Indonesia. Amsterdam: Amsterdam University Press, 2014.

Ginsburg, Tom. Judicial Review in New Democracies: Constitutional Court in Asian Cases. Cambridge: Cambridge University Press, 2003.

Gunther, Richard., José Ramón Montero and Juan Linz. Political Parties: Old Concepts and New Challenges: Old Concepts and New Challenges. Oxford: Oxford University Press, 2002.

Hardoon, Deborah and Finn Heinrich. Global Corruption Barometer 2013. Transparency International, 2013.

Haris, Syamsuddin. Masalah-Masalah Demokrasi dan Kebangsaan Era Reformasi. Jakarta: Yayayan Pustaka Obor Indonesia, 2014.

Haris, Syamsuddin. Pemilu Langsung di Tengah Oligarki Partai: Proses Nominasi dan Seleksi Calon Legislatif Pemilu 2004. Jakarta: Gramedia Pustaka Utama, 2005.

Haris, Syamsuddin. Praktik Parlementer Demokrasi Presidensial Indonesia. Jakarta: CV. Andi Offset, 2014. 174.

Harman, Benny K. Negeri Mafia Republik Koruptor: Menggugat Peran DPR Reformasi. Kupang: Penerbit Lamalera, 2012.

Horowitz, Donald L. Constitutional change and democracy in Indonesia. Cambridge: Cambridge University Press, 2013.

Legal Mafia Eradication Taskforce. Mafia Hukum. Jakata: UNDP and Legal Mafia Eradication Taskforce, 2010.

Shapiro, Martin and Alec Stone Sweet. On Law, Politics, and Judicialization. Oxford: Oxford University Press, 2002.

Wibowo, Pramono Anung. Mahalnya Demokrasi, Memudarnya Ideologi: Potret Komunikasi Politik Legislator-Konstituen. Jakarta: Penerbit Buku Kompas, 2013.

\section{Articles}

Bhakti, Ikrar Nusa. "DPR yang Terbelah.” Kompas. (3 November 2014).

G, Helmke. "The Logic of Strategic Defection: Judicial Decision Making in Argentina under Dictatorship and Democracy." American Political Science Review Vol. 96 Issue 2 (June 2002): 291-303.

Hamilton-Hart, Natasha. "Government and Private Business: Rents, Representation and Collective Action" in Indonesia: Democracy and The Promise of Good Governance edited by Ross H McLeod and Andrew MacIntyre. Institute of Southeast Asian Studies and the Indonesia Project of the Research School of Pacific and Asian Studies, The Australian National University, 2007. Pp. 93-114.

Harijanti, Susi Dwi and Tim Lindsey. "Indonesia: General Elections Test The Amended Constitution and The New Constitutional Court." International Journal of 
Constitutional Law (January 2006): 138-150.

Issacharoff, Samuel. "Constitutional Courts and Democratic Hedging." Georgetown Law Journal Vol. 99 (2011): 961-1012.

Joshihara, Anita and Haryo Damardono. “Koalisi Merah Putih Kuasai DPR." Kompas. (2 October 2014).

Katz, Richard S. and Peter Mair. "Changing Models of Party Organization and Party Democracy The Emergence of The Cartel Party." Party Politics Vol. 1 No. 1 (January 1995): 5-28.

Katz, Richard S. and Peter Mair. "The Cartel Party Thesis: A Restatement." Perspectives on Politics Vol. 7 No. 4 (December 2009): 753-766.

Kingsbury, Damien. "Indonesia in 2006: Cautious Reform." Asian Survey Vol. 47 No. 1 (January/February 2007): 155-161.

Kompas. "KPU Tetapkan Hasil Pileg." Kompas. (10 Mei 2014).

Kompas, "Amin Nasution-Azirwan Tersangka Penyuapan." Kompas $(10$ April 2008)

Krasner, Stephen D. "Approaches to the states", Comparatives Politics Vol. 16 No. 2 (Jan. 1984): 223-246.

Liddle, R. William. "Indonesia's Democratic Past and Future." Comparative Politics Vol. 24 No. 4 (July 1992): 443-462.

Liddle, R. William. "Indonesia in 1999: Democracy Restored." Asian Survey Vol. 40 No. 1 (Jan-Feb 2000): 32-42

Liddle, R. William and Saiful Mujani. "Leadership, Party and Religion: Explaining Voting Behavior in Indonesia." Comparative Political Studies Vol. 40 No. 7 (July 2007): 832-857.

Ufen, Andreas. "Political Party and Party System Institutionalization in Southeast Asia: Lessons for Democratic Consolidation in Indonesia, the Philippines and Thailand." Pacific Review Vol. 21 No. 3 (July 2008): 327-350.

Slater, Dan. "Indonesia's Accountability Trap: Party Cartels and Presidential Power After Democratic Transition." Indonesia Vol. 78 (October 2004): 61-92.

Stephenson, Matthew C. "“When the Devil Turns...": The Political Foundations of Independent Judicial Review." Journal of Legal Studies Vol. 32 (January 2003): 59-89.

Sun, Yan and Michael Johnston. "Does Democracy Check Corruption? Insights From China and India." Comparative Politics Vol. 42 No. 1 (October 2009): 1-19.

Tan, Paige Johnson. "Anti-Party Reaction in Indonesia: Causes and Implications." Contemporary Southeast Asia Vol. 24 No. 3 (December 2002): 484 -508.

Weatherbee, Donald E. "Indonesia: Electoral politics in a newly emerging democracy" in How Asia Votes edited by John Fuh-seng and David Newman. New York, Chatham House: Seven Bridges Press, 2002. Pp. 255-281.

\section{Websites}

Indosiar. "Presiden Bertemu Ketua MA dan Ketua KPK." http://www.indosiar.com/ fokus/presiden-bertemu-ketua-ma-dan-ketua-kpk_46458.html. Accessed 5 May 2015.

DetikNews. "Ketua MA Bagir Manan Diperiksa KPK di Kantornya." http://news. detik.com/read/2005/11/18/084611/480766/10/ketua-ma-bagir-manandiperiksa-kpk-di-kantornya?nd771104bcj. Accessed 5 May 2015.

Suara Pembaruan. "Inilah Peta Korupsi Yang Terjadi di DPR RI [Corruption Mapping in Parliament]". http://www.suarapembaruan.com/home/inilah-peta-korupsiyang-terjadi-di-dpr-ri/42900. Accessed 4 August 2014. 